\title{
Clinical Reasoning: A 12-month-old child with hypotonia and developmental delays
}

Elizabeth G. Ames, MD, PhD, Kerri L. Neville, MD, Nancy A. McNamara, MD, Catherine E. Keegan, MD, PhD, and Sarah H. Elsea, PhD

Neurology ${ }^{\circledR}$ 2020;95:184-187. doi:10.1212/WNL.0000000000009912
Correspondence

Dr. Ames

amese@med.umich.edu

\section{Section 1}

A 12-month-old girl was referred to the pediatric neuromuscular clinic for evaluation of hypotonia and weakness based on concerns from her pediatrician. The patient was born at term following an uncomplicated pregnancy, but developed failure to thrive and gross motor delays (unable to lift head in prone position) around 4 months of age. By 7 months of age, she began having episodes of bradypnea, tiring during feeds, acrocyanosis, and perioral cyanosis during periods of agitation.

During the clinic visit, the patient developed apnea and hypoxemia, and was subsequently admitted to the pediatric intensive care unit for respiratory failure requiring mechanical ventilation. On admission, her weight was approximately 50th percentile for a 6-week-old child, length was approximately 50th percentile for a 3-month-old child, and head circumference was approximately 50th percentile for a 6-month-old child. Her neurologic examination was remarkable for decreased mental status. She would respond to parents' voice with eye opening without ptosis, but was somnolent without vocalizations, and had a weak cry prior to intubation. She had minimal spontaneous movements in distal upper extremities and no spontaneous movements in her lower extremities. She was able to grip fingers with very little strength. She had diffuse hypotonia, complete head lag, and diminished deep tendon reflexes. No cherry red spot or optic atrophy was noted on ophthalmologic examination. Initial laboratory studies including electrolytes, complete blood count, infectious studies, $\mathrm{pH}$, and lactate were normal. An echocardiogram showed borderline right ventricular (RV) dilation and mildly elevated RV and pulmonary artery pressures. A 2-day video EEG was notable for diffuse slowing without focal or epileptiform abnormalities.

\section{Questions for consideration:}

1. What are possible localizations and diagnoses for this infant's hypotonia and weakness?

2. What testing would you consider?

\section{GO TO SECTION 2}

From the Departments of Pediatrics (E.G.A., C.E.K.) and Neurology (K.L.N., N.A.M.), University of Michigan Health System, Ann Arbor; and Department of Molecular and Human Genetics (S.H.E.), Baylor College of Medicine, Houston, TX.

Go to Neurology.org/N for full disclosures. Funding information and disclosures deemed relevant by the authors, if any, are provided at the end of the article. 


\section{Section 2}

Some plausible differential diagnoses based on localization include the following.

\section{Anterior horn cells}

The patient was referred for evaluation of spinal muscular atrophy (SMA), a genetic disorder causing progressive loss of anterior horn cells within the spinal cord. This patient's hypotonia, pattern of weakness (proximal $>$ distal), and decreased reflexes support this diagnosis. However, the acuity of the respiratory decompensation, cardiac involvement, and degree of failure to thrive would be atypical. $^{1}$

Infantile spinal muscular atrophy with respiratory distress type 1 (SMARD1) is a distinct genetic disorder presenting with intrauterine growth retardation, progressive distal weakness of the legs, and apnea. Our patient's weakness, failure to thrive, and rapid respiratory decline could fit this disorder. However, most cases present between 1 and 6 months of age with apneic respiratory failure.

\section{Diagnostic testing}

Molecular testing for the most common causes of SMA include deletion/duplication studies of SMN1 and SMN2 exon 7. SMARD1 is caused by biallelic pathogenic variants in the IGHMBP1 gene. Creatine kinase (CK) level is usually normal. Genetic testing has largely obviated the need for muscle biopsy or EMG testing. ${ }^{2}$

\section{Peripheral nerves}

There are rare causes of polyneuropathies with onset in infancy that can present with hypotonia and diminished reflexes. One subtle difference is the pattern of weakness and atrophy, which is usually more distal than proximal in contrast to anterior horn cell disease and myopathies. Decreased sensation is variable. Our patient's pattern of weakness did not fit this pattern, and sensation was intact. ${ }^{3}$

\section{Diagnostic testing}

EMG shows abnormal nerve conduction velocities, in contrast to SMA, which is associated with acute denervation and fibrillation potentials. Genetic testing panels for hereditary neuropathies are available.

\section{Myopathies}

Given the abnormal echocardiogram, myopathies, including glycogen storage disease type II (Pompe disease), should be considered. Infantile Pompe disease is characterized by weakness, hypotonia, cardiomegaly, and elevated $\mathrm{CK}$. It is caused by a deficiency in the lysosomal enzyme acid $\alpha$-glucosidase (GAA), which leads to abnormal glycogen accumulation in skeletal, cardiac, and smooth muscle. Glycogen accumulation is also seen in the CNS, leading to a mixed central and peripheral nervous system presentation. ${ }^{4}$

\section{Diagnostic testing}

$\mathrm{CK}$ elevation is a strong indication for additional testing. GAA enzyme activity and gene sequencing confirm the diagnosis. With the possibility for enzyme replacement therapy, Pompe disease is now included on the newborn screen in some states.

Similarly, mitochondrial myopathies could also be considered. Mitochondrial diseases include a range of disorders that can affect various organ systems, preferentially affecting systems with high metabolic demands such as muscle. Other features of mitochondrial disorders include stroke-like episodes, deafness, diabetes, or optic atrophy, which would not be expected in an infant with a mitochondrial disorder.

\section{Diagnostic testing}

Screening laboratory studies include lactate, pyruvate, plasma amino acids, and urine organic acids. CSF testing includes lactate, pyruvate, and amino acids. Combined mitochondrial and nuclear sequencing can be definitive, ${ }^{5}$ but genetic testing may need to be done on affected tissue such as muscle.

Congenital myopathies typically involve elevated CK levels and more prominent facial weakness and ptosis compared to our patient. ${ }^{6}$

\section{Central causes}

Mixed central and peripheral nervous system processes include the broad category of leukodystrophies. Often

Figure MRI examination of brain and cervical spine
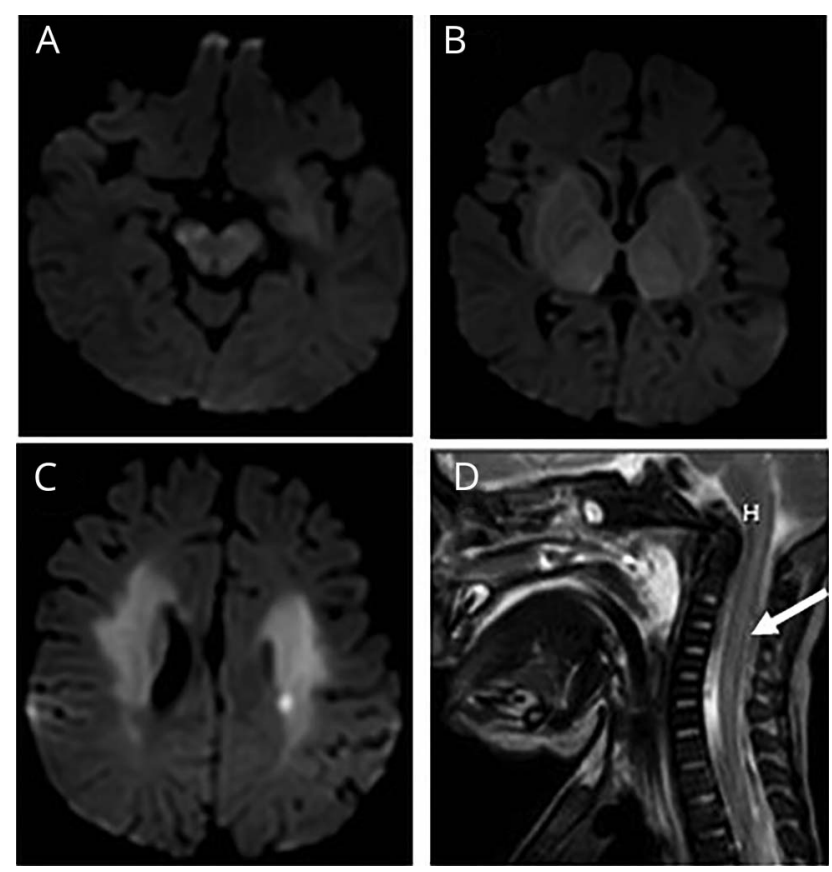

(A-C) Axial MRI brain diffusion-weighted imaging. (D) Sagittal cervical spine MRI T2-weighted sequence with arrow indicating abnormality. 
these present with spasticity and increased reflexes (upper motor neuron signs given white matter involvement), but also affect the peripheral nervous system, leading to a mixed clinical picture (table e-1, links.lww.com/ WNL/B126).

\section{Diagnostic testing}

MRI brain with spectroscopy is needed. Further biochemical and genetic testing can be performed depending on clinical presentation and pattern of imaging abnormalities.

Lysosomal storage disorders can present with leukodystrophy (see table e-1, links.lww.com/WNL/B126) or with mixed localization findings. Tay-Sachs disease and Niemann-Pick disease types $\mathrm{A}$ and $\mathrm{B}$ are associated with the distinct cherry red spot on ophthalmologic examination, which our patient did not have. The lack of cherry red spots does not exclude these diagnoses in older patients given that it can disappear over time. $^{7}$
Within 2 days of admission, SMA testing was normal, prompting consideration of a broader differential diagnosis. Plasma amino acids were notable for low essential amino acids and mildly elevated glycine. Plasma lactic acid was normal. Plasma metabolomics showed evidence of liver dysfunction and supported the findings of low essential amino acids and mild elevations in glycine. Numerous CSF studies were sent including neurotransmitters, lactate, pyruvate, and metabolomics. CSF lactate, amino acids, and metabolomics showed markedly elevated levels of lactate and glycine, in contrast to the plasma studies.

Brain and spine MRI with spectroscopy was performed (figure). Magnetic resonance spectroscopy demonstrated a large lactate doublet.

\section{Questions for consideration:}

1. How would you interpret the MRI results?

2. Based on the results of the MRI, how would you prioritize further testing at this point? 


\section{Section 3}

MRI brain revealed extensive, symmetric diffusion restriction prominent in the bilateral basal ganglia and thalami, extending into frontoparietal white matter, brainstem, cerebral peduncles, and midbrain. MRI of the spinal cord showed intramedullary, longitudinally extensive $\mathrm{T} 2$ signal hyperintensities throughout the central cord. The elevated lactate on magnetic resonance spectroscopy and symmetric involvement of the basal ganglia and thalami suggested a primary metabolic or mitochondrial process. This pattern can be seen in maple syrup urine disease (MSUD), although the patient's clinical presentation and biochemistry did not fit with MSUD.

Additional genetic testing included whole exome sequencing (WES) with mitochondrial sequencing. Before the results of WES returned, the patient had another episode of decompensation and developed fixed, unresponsive pupils. With her progressive clinical presentation, the family elected to pursue comfort care and she died shortly after extubation ( 8 days after admission). Her autopsy revealed a small for age, nondysmorphic, female infant with subacute thalamic infarcts, acute global hypoxic ischemic brain injury, cardiomegaly, hypertensive changes in the pulmonary vasculature, and type 2 fiber atrophy of skeletal muscle.

Her WES identified 2 variants of uncertain significance (VUS) in the NFU1 gene. VUS often require additional evidence in order to confirm pathogenicity. The paternally inherited VUS (NM_001002755.2 c.398T > C; p.Leu133Pro) has not been reported in large population cohorts, but is predicted to be damaging. The maternally inherited VUS (NM _001002755.2 c.299C > G; p.Ala100Gly) is present in large population cohorts at a very low frequency. ${ }^{8}$ There were conflicting computational predictions regarding the effect of the maternal VUS on protein structure and splicing, which made the significance of this VUS challenging to interpret.

\section{Discussion}

Multiple mitochondrial dysfunctions syndrome (MMDS) is associated with 6 autosomal recessive genes including NFU1. All genes associated with MMDS are involved in the production of iron-sulfur clusters that are required for multiple mitochondrial enzymes including enzymes responsible for glycine breakdown and involved in MSUD. Patients usually present within 18 months of life with early-onset encephalopathy, hypotonia, developmental delays, pulmonary hypertension, acute neurologic decompensation with apnea, and cavitating leukoencephalopathy, which fit our patient's presentation. ${ }^{9}$

Our case highlights the differential for a profoundly hypotonic infant with diminished reflexes. Rare genetic disorders like MMDS can be challenging to diagnose without WES. The VUS detected were not diagnostic alone, but metabolomic profiling provided additional biochemical evidence confirming the diagnosis of NFU1-related MMDS. Metabolomic profiling is a promising technology in the diagnosis of biochemical disorders. ${ }^{10}$ The use of an untargeted metabolic assay in this case allowed for detection of abnormalities that were diagnostic of a rare biochemical disorder and provided additional evidence that the NFU1 VUS were pathogenic. The differences between plasma and CSF is another notable feature of this case, emphasizing that CSF studies can provide further diagnostic information for neurologic and mitochondrial disorders.

\section{Study funding}

No targeted funding reported.

\section{Disclosure}

E. Ames, K. Neville, N. McNamara, K. McFadden, C. Keegan, and $S$. Elsea report no disclosures relevant to the manuscript. $S$. Elsea receives research funding from the NIH, Smith-Magenis Syndrome Research Foundation, Shire Genetic Therapies, and PRISMS, Inc. Go to Neurology.org/N for full disclosures.

\section{Appendix Authors}

\begin{tabular}{|c|c|c|}
\hline Name & Location & Contribution \\
\hline $\begin{array}{l}\text { Elizabeth G. } \\
\text { Ames, MD, } \\
\text { PhD }\end{array}$ & $\begin{array}{l}\text { Department of Pediatrics, } \\
\text { University of Michigan, Ann } \\
\text { Arbor }\end{array}$ & $\begin{array}{l}\text { Drafting case report, } \\
\text { review of the literature, } \\
\text { interpretation of } \\
\text { metabolomic profiling }\end{array}$ \\
\hline $\begin{array}{l}\text { Kerri L. } \\
\text { Neville, MD }\end{array}$ & $\begin{array}{l}\text { Department of Neurology, } \\
\text { University of Michigan, Ann } \\
\text { Arbor }\end{array}$ & $\begin{array}{l}\text { Drafting case report, } \\
\text { review of the literature }\end{array}$ \\
\hline $\begin{array}{l}\text { Nancy A. } \\
\text { McNamara, } \\
\text { MD }\end{array}$ & $\begin{array}{l}\text { Department of Neurology, } \\
\text { University of Michigan, Ann } \\
\text { Arbor }\end{array}$ & $\begin{array}{l}\text { Critically reviewing } \\
\text { manuscript }\end{array}$ \\
\hline $\begin{array}{l}\text { Catherine E. } \\
\text { Keegan, MD } \\
\text { PhD }\end{array}$ & $\begin{array}{l}\text { Department of Pediatrics, } \\
\text { University of Michigan, Ann } \\
\text { Arbor }\end{array}$ & $\begin{array}{l}\text { Critically reviewing } \\
\text { manuscript }\end{array}$ \\
\hline $\begin{array}{l}\text { Sarah H. } \\
\text { Elsea, PhD }\end{array}$ & $\begin{array}{l}\text { Department of Molecular } \\
\text { and Human Genetics, } \\
\text { Baylor College of Medicine, } \\
\text { Houston, TX }\end{array}$ & $\begin{array}{l}\text { Critically reviewing } \\
\text { manuscript, interpretation } \\
\text { of metabolomic profiling, } \\
\text { final approval of the } \\
\text { version to be published }\end{array}$ \\
\hline
\end{tabular}

\section{References}

1. Kolb SJ, Coffey CS, Yankey JW, et al. Natural history of infantile-onset spinal muscular atrophy. Ann Neurol 2017;82:883-891.

2. Viguier A, Lauwers-Cances V, Cintas $P$, et al. Spinal muscular atrophy with respiratory distress type 1: a multicenter retrospective study. Neuromuscul Disord 2019;29: 114-126.

3. Baets J, Deconinck T, De Vriendt E, et al. Genetic spectrum of hereditary neuropathies with onset in the first year of life. Brain 2011;134:2664-2676.

4. Pena LDM, Proia AD, Kishnani PS. Postmortem findings and clinical correlates in individuals with infantile-onset Pompe disease. JIMD Rep 2015;23:45-54.

5. Ahmed ST, Craven L, Russell OM, Turnbull DM, Vincent AE. Diagnosis and treatment of mitochondrial myopathies. Neurotherapeutics 2018;15:943-953.

6. Gilbreath HR, Castro D, Iannaccone ST. Congenital myopathies and muscular dystrophies. Neurol Clin 2014;32:689-703.

7. Chen H, Chan AY, Stone DU, Mandal NA. Beyond the cherry-red spot: ocular manifestations of sphingolipid-mediated neurodegenerative and inflammatory disorders. Surv Ophthalmol 2014;59:64-76.

8. Lek M, Karczewski KJ, Minikel EV, et al. Analysis of protein-coding genetic variation in 60,706 humans. Nature 2016;536:285-291.

9. Ahting U, Mayr JA, Vanlander AV, et al. Clinical, biochemical, and genetic spectrum of seven new patients with NFU1 deficiency. Front Genet 2015;6:1-13.

10. Miller MJ, Kennedy AD, Eckhart AD, et al. Untargeted metabolomic analysis for the clinical screening of inborn errors of metabolism. J Inherit Metab Dis 2015;38: 1029-1039. 


\section{Neurology}

\section{Clinical Reasoning: A 12-month-old child with hypotonia and developmental delays}

Elizabeth G. Ames, Kerri L. Neville, Nancy A. McNamara, et al.

Neurology 2020;95;184-187 Published Online before print July 15, 2020

DOI 10.1212/WNL.0000000000009912

This information is current as of July 15, 2020

Updated Information \& Services

References

Subspecialty Collections

Permissions \& Licensing

Reprints including high resolution figures, can be found at: http://n.neurology.org/content/95/4/184.full

This article cites 10 articles, 0 of which you can access for free at: http://n.neurology.org/content/95/4/184.full\#ref-list-1

This article, along with others on similar topics, appears in the following collection(s):

Developmental disorders

http://n.neurology.org/cgi/collection/developmental_disorders Leukodystrophies

http://n.neurology.org/cgi/collection/leukodystrophies

Mitochondrial disorders

http://n.neurology.org/cgi/collection/mitochondrial_disorders

MRI

http://n.neurology.org/cgi/collection/mri

Information about reproducing this article in parts (figures,tables) or in its entirety can be found online at:

http://www.neurology.org/about/about_the_journal\#permissions

Information about ordering reprints can be found online:

http://n.neurology.org/subscribers/advertise

Neurology ${ }^{\circledR}$ is the official journal of the American Academy of Neurology. Published continuously since 1951, it is now a weekly with 48 issues per year. Copyright () 2020 American Academy of Neurology. All rights reserved. Print ISSN: 0028-3878. Online ISSN: 1526-632X.

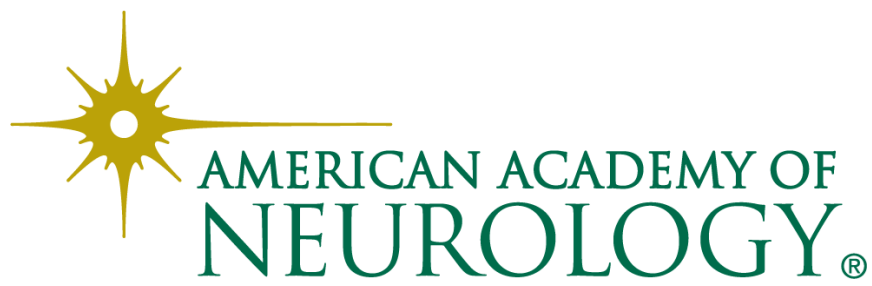

